\title{
NEW NATURE RESERVES IN ENGLAND AND WALES
}

$\mathrm{T}$ HREE new nature reserves in England and one in Wales were declared by the Nature Conservancy on November 24 , and a further two acres were added to the Bridgwater Bay Nature Reserve, by the declaration of Steart Island, off the mouth of the River Parret, on the termination of an existing tenancy. Steart Island, which is separated from the mainland at high tide by half a mile of water, is the roosting-place for hundreds of geese, mainly whitefronted geese, and is the only known area in Britain where moulting shelduck gather each summer; for this reason it is hoped to keep the island entirely undisturbed.

Cwm Idwal Nature Reserve, the first Welsh nature reserve, and the first to be declared in a national park, is a natural amphitheatre rising to above $3,200 \mathrm{ft}$. in the heart of Snowdonia National Park, about four miles north of Snowdon, and this 984-acre area has been leased to the Conservancy by the National Trust, subject to existing farm tenancies. Its wide variety of volcanic rocks carries an interesting flora, dating from immediately after or even before the latest Ice Age. Green spleenwort, lloydia, purple saxifrage, water lobelia and quillwort are found there. The University College of North Wales, Bangor, will continue to use Cwm Idwal for botanical, research and teaching purposes, and the Conservancy's own work will probably include work on the interrelation of vegetation and soils and the effect of grazing on some of the important plant communities. Climbers and mountaineers accustomed to visit the area will find no change in access; but formal applications must be made for research in the Reserve or for collecting specimens of animals or plants.

Blelham Bog Nature Reserve, lying on the northwestern edge of Blelham Tarn, three and a half miles south-west of Ambleside, is a rare example of the development of sphagnum bog from wet wild wood- land, very little of which now remains. The vegetation is mainly Sphagnum-Molinia-Myrica bog with unusual species such as great sundew, white beaksedge and downy sedge and many of the bog mosses characteristic of this type of transitional environment. Of the caddis flies found there, limnophilus xanthodes McLachlan, extremely rare elsewhere in the Lake District, is fairly abundant. Access will not be restricted; but permits will be required for the collection of animals or plants in the Reserve.

The chief interest of Hartland Moor Nature Reserve, which covers 178 acres close to the Conservancy's Research Station at Furzebrook and is about one and a half miles south-east of Wareham, Dorset, is the domination of the vegetation in parts by the rare Dorset heath (Erica ciliaris). Other rare bog plants are also found in the Reserve, and there are interesting local variations in the flora, probably related to differences in the drainage. Public access will not at present be restricted; but permits will be required for collecting.

Ame Nature Reserve is a small section of Big Wood, about two and a half miles east of Wareham, and is one of the two known places in the country which show the natural transition from dry woodland to salt marsh-a brackish tidal condition. Parts of the wood probably represent the remains of the primitive broad-leaved forest; but it also contains such interesting features as the rare royal fern (Osmunda regalis) in a natural habitat. There are valuable potentialities for scientific research, notably into the effects of water-logging and the transition between salt marsh and either woodland or heathland. Cord grass (Spartina townsendii) is present on the seaward fringe, where studies will be linked to the experiments on coastal vegetation at Bridgwater Bay. Permission to visit will be required, and also authority to undertake research or collect specimens.

\section{INSTITUTE OF PERSONNEL MANAGEMENT}

\section{ANNUAL CONFERENCE}

$\mathrm{A}^{\mathrm{T}}$ $T$ the forty-first annual conference of the Institute of Personnel Management, which was held at Harrogate during October 8-10, the opening speaker was Admiral Sir Denis Boyd, principal of Ashridge College. On the general theme of leadership, Sir Denis said that he is convinced that people cannot be trained in its most important aspects. In leadership there is a combination of technique and personality; the technique can and should be taught to everyone in any kind of authority, the crux of the technique being administration. Problems are not solved by inspired decisions, he continued, but by constant thought, intelligent anticipation, waiting, foresight, patience and organization-that is, administration. The delegation of responsibility is the key to wise administration. Among the attributes of leaders are enthusiasm, austerity, sincerity, courage and humility.

Sir Miles Thomas, chairman of the British Overseas Airways Corporation, discussed the changing pattern of British industrial management. First, he said, there was the development of specialized management - the breakdown of management into a variety of techniques. In the early days of British industry and up to the early years of the twentieth century, the 'boss' of the firm was the owner. He alone carried the risk of losses and reaped the reward of profit; it was his financial credit, and that of the bank, which determined how easily he could get fresh capital for expansion. The owner naturally had the undisputed right to 'hire and fire' when and how he liked and, within brosd limits, to pay just as much or as little regard as he felt inclined to working conditions or to wages.

Gradually, the demands of technical development, commercial competition and, above all, of the pressing need to raise more capital to keep pace with the growing scale of operations and expansion, produced two changes almost simultaneously. First, the owner found that, to obtain the necessary capital, he was compelled to turn the concern into a joint stock company, with ownership in the hands of the 
stockholders, while he himself was appointed managing director. Secondly, the scale of the managerial problem presented by the growth in size and complexity of the business meant that no longer could he, even as managing director, deal with every side of the business himself. From this situation there emerged the manager as a person and a position to be respected. He became the final authority from whom originated instructions on policy and on their execution. Inevitably there grew up specialists in the various branches of management. Production and sales were the first to be clearly separated, and these were followed by various dichotomies and drafting processes until, by the end of the First World War, the familiar pattern of production, sales, finance. research, planning and buying was becoming the general rulo.

This division of labour at the highest level called at once for a better quality of general management than had hitherto been required. The second feature of the industrial and commercial management scene was the changing balance of emphasis and importance between the several elements of specialist management. The period immediately after the First World War was mainly one of developing the selling power of British goods. Consumers had to be found and shown that their interest was best served by buying a particular line of goods. Above all, the sales manager had to have sufficient authority to see to it that the technical or production departments produced the goods he wanted. In response to the developing authority of the sales department, powerful incentive was also provided for the development of research in industry, both of a fundamental nature and in the various technological processes. This era of the growing power of sales management was succeeded by the development of financial management. Tho growing complexity of the financial structure of the big joint stock company, the stringent requirements of the various Company Acts and the ever-pressing pressure of the Inland Revenue, produced a demand for experts in this field to be represented in the executive management of most concerns of any size.

The end of the Second World War saw the emergence into a new importance of the latest development of specialized management--personnel. Due to the immensely significant social and economic changes in the years immediately following the Second World War, there was at once an overwhelming and critical demand from men and women in industry to be regardod each as individuals with rights and responsibilities. This meant that the element of executive management which should be the last which any managing director wishes to delegate became rapidly of vast and specialized importance in the form of a personnel or employee relations department. This further specialization of management into personnel or staff management shows the emergence of the conception of the responsibility of industry to society.

There seem to be three main ways in which developing economic and social patterns have emphasized the importance of personnel management since the War. First, the significance of the individual has been underlined in a purely practical way. It has been generally appreciated that the application of large sums of money and intense research effort by the best technical brains available to securing and devising exactly the right piece of equipment to perform a certain job can be rendered largely nugatory if the men and women who operate it are so ill-suited to the task that they do not get the best out of it. Secondly, society's demand for equality and justice generally bears directly on the personnel manager's job. In this context there is also the vastly important field of relations with the trade unions. Thirdly, the personnel function has been heavily emphasized by the vast range of problems involved in getting more out of a group of people than the sum of their individual efforts.

Mr. C. J. Geddes, president of the Trades Union Congress, considered the role of trade unions in the future. During and after the Second World War, he said, there has been a profound change in the attjtude of the trade union movement, and an attempt is being made to avoid a clash with employers and management. In the immediately foreseeable future, however, the fundamental purpose of the trade union movement will not change, nor will officials cease to strive in every possible way to get every farthing they can for their members. They will not abandon their right to use force. The driving spirit of the trade union movement does not rest with the leader, nor is the policy determined by the leader, but by the individual member.

There has been no fundamental change in the outlook, purpose or objective of the trade union movement, continued Mr. Geddes. 'The trade union leader is no longer a bitter enemy of the employer; but he is not yet his friend. There is not the slightest hope in the foreseeable future of the trade union movement agreeing to a national wages policy, not only because of the extreme difficulty of trying to devise one, but also because the trade union move. ment would largely sacrifice its purpose if it did so.

Will the trade unions demand a greater share in the management of industry? Mr. Geddes thinks they will, and it may be one of the major differences between the trade union movement and the employers in the immediate future. This does not mean that trade unions are going to demand that they must have joint control, but that they should become more and more equal with management and have much more information about the operation of particular industries.

Looking at the industrial scene, Mr. J. B. Priestley, the author, declared that there is a danger that our highly industrialized urban life may rob mon of so many of the primary satisfactions that, in their sense of frustration and resentment, they may create a society so violent that it will explode in our faces. There are certain things men and women want : the English love to use their energy intermittentlythey do not want to use the same amount every day, or to be harnessed to something keeping a regular tempo. He hoped that, as industry develops, it will be possible to make machines gear themselves to men and not men to machines. Everything - - even employment and hours of work-is too regular : people do the same dullish job too long. We are in danger of creating a highly industrialized society which has lost all feeling for the soul or for any notion of man as a spiritual being-a society that might imitate the crueltios of ancient Rome to release its feelings of frustration.

The second danger in this industrial age, continued Mr. Priestley, is that the future organization of human affairs may deteriorate because we are not producing good human beings to take charge of 
them. We spend thousands of pounds on education, but to what end ? It is no good pouring money into a school unless we are going to spend money and take time and trouble over the street outside the school; environment will always defeat education. Looking at Britain as an environment, it is important to think of the forces playing on the people personnel managers have to handle: we should think of the way such people are not encouraged to think for themselves at all. The reason why young working people are not showing any sort of enterprise is the recent creation of a complete mass working-class culture.

To keep industry going, we need a fair proportion of young men and women who are individuals with initiative, who think for themselves and have some sense of mental and spiritual development. We should do everything to make that possible, because we do not want our great-grandchildren to be living in an ant-heap and to be indistinguishable from the robots they might be making to serve them.

A valuable feature of the Conference was a number of 'brains trusts' sessions at which experienced personnel officers answered questions on such varied themes as work and health; management training courses; wage differentials ; and discipline and full employment.

T. H. Hawkins

\section{NUTRITION AND THE ALIMENTARY TRACT IN MAN}

$\mathrm{T}$ HE Scottish Group of the Nutrition Society held a conference in Dundee on October 23 on "Disorders of the Alimentary Tract and their Nutritional Effects". In discussing disorders of fat absorption, Dr. J. M. French (Department of Pharmacology, University of Birmingham) said that fat absorption is defective in many clinical conditions, often as part of a generalized absorptive defect. Assessment of the degree of defect of fat absorption cannot be made by microscopic examination or percentage fat in the wet or dry freces, and some type of fat balance must be employed. A continuous study of fat absorption, using the rapid daily fattyacid estimation of Kamer, Huinink and Weijers, is essential if results of treatment or other procedures are to be assessed in a reasonable period of time. The accumulation of data with the same rapidity by the use of balances at intervals is precluded by the great day-to-day variability shown by subjects with defective fat absorption. The continuous method is especially applicable to such problems as the effective replacement therapy of pancreatic insufficiency with various types of pancreatic extract.

Wheat and rye gluten as a causative factor in cœliac disease, originally demonstrated in Holland by Dicke, Weijers and Kamer, has been amply confirmed in Britain. Although many adult cases of idiopathic steatorrhoea have a history of coliac disease in childhood, the response of the adult to a wheat gluten-free diet is disappointing. Five cases of complete recovery have been recorded, however, suggesting that it is the basic factor. Failures may be due to superimposed vitamin deficiency, sensitivity to factors other than wheat and rye protein, or increased bacterial growth in the rich medium provided by the slow absorption of food. Evidence for the latter in tropical sprue has been provided by the use of intestinal chemotherapy.
Specific infection, dietary deficiency and tropical conditions are unsatisfactory as theories for the primary cause of tropical sprue. Considerable evidence has been accumulated to suggest that oxidative rancidity of unsaturated cooking oils may start tropical sprue, the intestine being irritated by some chemical constituent. This evidence is provided by the fact that sprue is rare in tropical countries such as Africa where saturated fats are consumed, but common in India and the Far East where cooking oils, such as rapeseed, sesame and mustard oil, are consumed. The high incidence in India among European and Indian troops during 1942-45 coincided with a change in dietary fat intake both in quantity and type, which would be in conformity with this theory. Experimental support is given by work in rats, which rapidly develop diarrhœea, steatorrhœa, emaciation, anæmia and death, if fed on rancid unsaturated fats.

Dr. R. H. Girdwood (Department of Medicine, Univer'sity of Edinburgh) spoke on the occurrence of vitamin-deficiency conditions related to disorders of the alimentary tract. Conditions that interfere with vitamin intake include destruction of the area of the stomach that secretes the 'intrinsic factor'; rapid passage of vitamins particularly as a result of fistulæ; stagnant or blind loops of small intestine; and disease of the intestine or mesenteric glands.

Clinical impressions of specific vitamin deficiencies are misleading, and biochemical loading tests are not very satisfactory. Nevertheless, a differential urinary folic-acid excretion test is of diagnostic value in showing poor absorption of folic acid in conditions such as idiopathic steatorrhœea. After total or partial gastrectomy operations, or even after a gastro-enterostomy, megaloblastic anæmia may develop ; steatorrhoea may also occur, but serum vitamin $B_{12}$ tests show that the deficiency is of vitamin $\mathrm{B}_{12}$ and not folic acid. Where an anæmia is the result of a stagnant loop, it may not respond to any vitamin therapy, and presumably toxins are being absorbed from the loop.

The interpretation of studies of vitamin balance is complicated by the metabolism of the microbes found in the alimentary tract. Strains have been demonstrated both to synthesize and to absorb such vitamins as cyanocobalamine; their net influence is still uncertain, and may vary in different conditions.

Dr. D. A. K. Black (Department of Medicine, Royal Infirmary, Manchester) discussed the effects of alimentary disease in mineral metabolism. In general, chronic alimentary disease leads to mineral malnutrition as a result of deprivation and malabsorption of food minerals, while in acute catastrophes the loss of alimentary secretions is the predominant feature. Disease of the alimentary tract is the principal cause of potassium depletion, and has been demonstrated in pyloric stenosis, gastro-enteritis, ulcerative colitis and steatorrhcea and even as a consequence of excossive use of laxatives. This may result from deprivation of food intake, which is usually of the order of 100 m.equiv. daily, increased loss in the stools, and loss by vomiting. The potassium content of alimentary secretions is about one-tenth of the sodium content, so that in acute disturbances sodium depletion predominates; nevertheless, significant loss of potassium may occur, in chronic disease partly because colonic absorption of potassium is much less complete than that of sodium and partly because renal loss of potassium is greater than that of sodium when there are comparable body deficits of the two 